\title{
Effect of Two Allexivirus Isolates on Garlic Yield
}

E. E. Cafrune, M. C. Perotto, and V. C. Conci, Instituto de Fitopatología y Fisiología Vegetal, Instituto Nacional de Tecnología Agropecuaria (IFFIVE-INTA) Camino 60 cuadras km 5 1⁄2 (5119) Córdoba, Argentina

\begin{abstract}
Cafrune, E. E., Perotto, M. C., and Conci, V. C. 2006. Effect of two Allexivirus isolates on garlic yield. Plant Dis. 90:898-904.

Garlic (Allium sativum) is infected by numerous viruses forming a viral-complex, which is widely distributed in the garlic production regions of Argentina. This work is the first report of the effect of two Allexivirus isolates, Garlic virus A (GarV-A) and Garlic virus C (GarV-C), on garlic yield. Garlic cvs. Morado-INTA and Blanco-IFFIVE were used in the experiments, and four treatments were evaluated: plants inoculated with GarV-A only, GarV-C only, virus-free plants (negative control), and plants infected with the virus-complex. Assays were performed in anti-aphid cages and in the field during 2002 and 2003. GarV-A caused significant reductions in bulb weight (14 to $32 \%$ ) and diameter (6 to $11 \%$ ) compared with the negative control in the two cultivars under both assay conditions. GarV-C caused less damage than GarV-A (15\% in weight and 5\% in diameter) with respect to the negative control in cv. Blanco-IFFIVE, and did not produce significant yield losses in cv. Morado-INTA in either year or under either assay condition.
\end{abstract}

Additional keywords: garlic mite-borne virus, garlic mosaic

Garlic (Allium sativum L.) is infected by numerous systemic viruses that are spread widely by the seed bulbs due to exclusive vegetative propagation of the crop. Thus, the viruses accumulate in plants over time and form a viral complex composed of different species producing a disease known as garlic mosaic. Onion yellow dwarf virus (OYDV), Leek yellow stripe virus (LYSV), Shallot latent virus (SLV), and Garlic common latent virus (GCLV) have been cited as aphid-borne viruses infecting garlic $(2,10,17,18,34,35)$. Other garlic viruses are transmitted by mites $(1,21,36,37)$ and have been grouped in the genus Allexivirus (38). Based on the nucleotide sequence, different virus species have been detected within the genus Allexivirus, such as Garlic viruses $A, B, C, D, E$, and $X(G a r V-A, B, C, D, E$, and $X)(7,8,23,29,31,33)$. The sequence of an Allexivirus species, Garlic mite borne filamentous virus (accession no. X98991) (21), detected in Argentina showed $91 \%$ homology of viral coat protein (CP) amino acid sequence and $98 \%$ homology of $3^{\prime}$ noncoding nucleotide sequence with GarV-A from Japan (31). Given this high sequence homology, it was designated GarV-A. This virus was detected in most of the garlic production areas in Argentina, with an incidence

Corresponding author: Vilma C. Conci

E-mail: vconci@correo.inta.gov.ar

Accepted for publication 14 February 2006.

DOI: 10.1094/PD-90-0898

(c) 2006 The American Phytopathological Society ranging from 35 to $64 \%$ depending on the region (26).

Another Allexivirus, serologically identified as GarV-C, has been isolated in Argentina by mechanical transmission from infected garlic to Chenopodium murale (3). The GarV-A and GarV-C tested in this work are widely distributed in the garlic production regions where allexiviruses were studied $(3,8,19-21,30,33)$.

The greatest economic losses in garlic have been attributed to OYDV, and to a lesser degree, to LYSV $(4,24,27)$. Reductions of the bulb weights of White garlic type and cv. Rosado Paraguayo in Argentina (60 and 53\%, respectively) by virusfree plants and plants infected with the viral complex have been reported $(4,12)$. Some reports suggest that mite-borne viruses may negatively influence yields of garlic (36), but this has not been demonstrated. The lack of information available about the effect of the viruses on garlic yield is due to the difficulty in isolating each viral species from the garlic virus complex and to the lack of specific antisera against each virus species. This paper reports the effect of two Allexivirus (GarV-A and GarV-C) isolates on garlic yield.

\section{MATERIALS AND METHODS}

Serological assays and antisera. Virus infection was assessed using the doubleantibody sandwich enzyme-linked immunosorbent assay (DAS-ELISA), following the protocol described by Clark and Adams (9) and adjusted for garlic by Conci et al. (15). Immunosorbent electron microscopy plus decoration (ISEM-D) (28) was also used for selecting the virus-free plants and plants infected with GarV-A and GarV-C.
Antisera against OYDV, LYSV, GarV-A, and MIX-antiserum obtained from garlic plants infected with the mixture of viruses that naturally affect garlic were used, taken from the stock of IFFIVE-INTA, and obtained as described in Conci et al. (14), Lunello et al. (25), and Helguera et al. $(21,22)$, respectively. Mixed antiserum basically detects Allexivirus and Carlavirus (V. C. Conci, unpublished results). GCLV and GarV-D antisera were kindly provided by D. E. Lesemann, H. J. Vetten, and E. Barg from BBA, Braunschweig, Germany; SLV by L. Bos and D. Z. Maat from the Research Institute for Plant Protection, Wageningen, Netherlands; and GarV-C and GarV-A by S. Sumi from the Institute for Biotechnology Research, Wakunaga Pharmaceutical. Another antiserum obtained from a mixture of garlic viruses was kindly provided by M. Carvalho from UFV from Viçosa, Brazil, and R. Shepherd from the University of California, Davis $(5,6)$. It was demonstrated that this antiserum basically detects Allexivirus (V. C. Conci, unpublished results).

Isolation of Allexivirus. GarV-C and GarV-A viruses were isolated from garlic plants chronically infected by the virus complex. Leaves were macerated in a borate buffer solution $(0.05 \mathrm{M}, \mathrm{pH} 8.1)$ and mechanically transmitted with 300 mesh Carborundum to Chenopodium murale plants, in which Allexivirus produces local lesions (37). Plants were checked periodically for symptom expression. Tissue from each lesion obtained was macerated in the same buffer solution and used as inoculum to infect new leaves of $C$. murale, one leaf with each lesion. This procedure was repeated six times to obtain virus isolates. Sixteen possible isolates were obtained, from which one was identified as GarV-C and another as GarV-A. To confirm the purity of the isolates, they were tested by ISEM-D with dilution of 1:500 for the coating antiserum and serial double dilutions ranging from $1: 25$ to $1: 6,400$ for decoration of the homologous antiserum to detect possible differences in the intensity of the viral particles decoration. Each virus isolate was maintained and multiplied in C. murale through mechanical inoculations. The identity of the viral isolate was confirmed periodically by ISEM-D with the specific antisera mentioned.

Plant material. Two garlic cultivars were used: Morado-INTA, a selection from Asiatic garlic with short growth cycle (230 days), belonging to the germ plasm bank of La Consulta INTA Experimental 


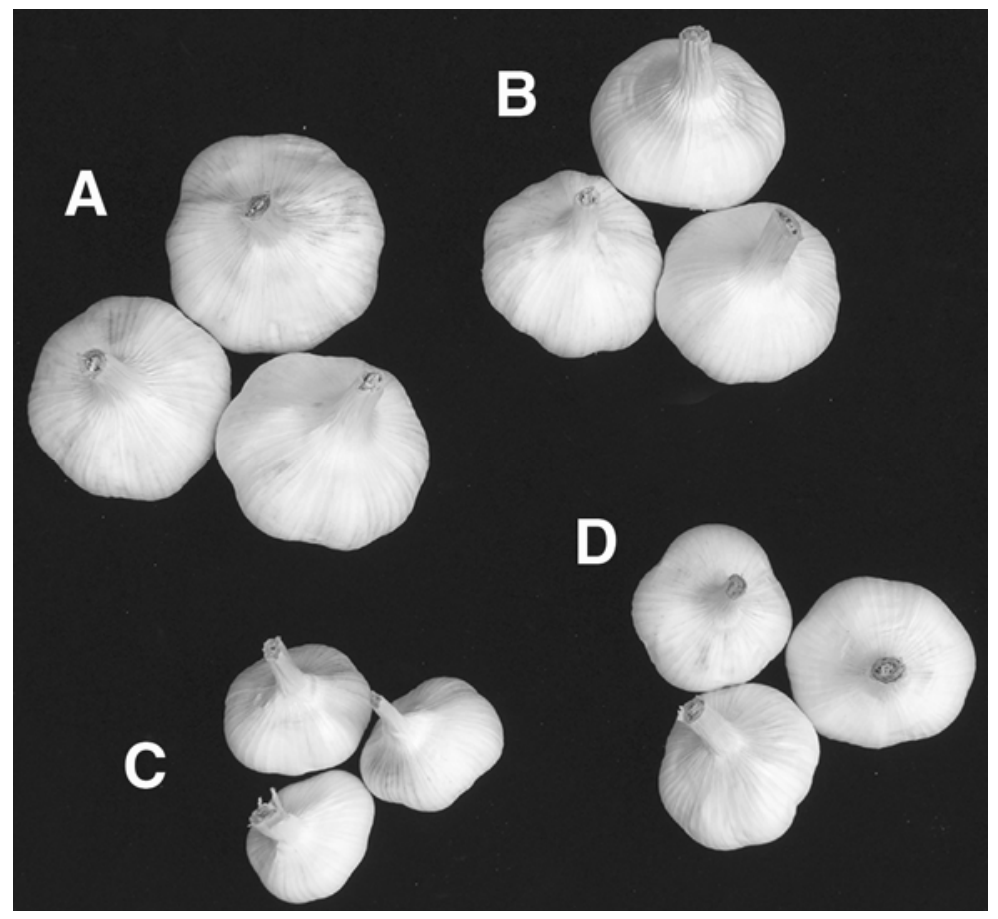

Fig. 1. Differences between garlic bulbs: A, negative control; B, plants inoculated with Garlic virus $C$ only C-treatment; C, virus-complex treatment, and D, plants inoculated with Garlic virus A only, Atreatment in cv. Blanco IFFIVE.
Agricultural Station from Mendoza, Argentina; and Blanco-IFFIVE, a selection of the Institute of Phytopathology and Plant Physiology, National Agricultural Technology Institute (IFFIVE-INTA) from Córdoba, Argentina, belonging to the White garlic type with a crop cycle of 210 to 230 days. Both cultivars are cultivated in the most important Argentine garlic producing regions.

Virus-free garlic plants (negative controls) used as healthy controls were obtained by thermotherapy followed by meristem culture $(11,16)$. These plants were hardened and multiplied in anti-aphid cages and analyzed by ISEM-D using the antisera mentioned above. Garlic plants chronically infected with virus complex positive to OYDV, LYSV, GarV-A, GarV$\mathrm{C}$, GarV-D, and GCLV antisera (viruscomplex treatment) were used as positive controls.

GarV-C and GarV-A isolates were transmitted to virus-free garlic planted in separate anti-aphid cages ( $\mathrm{C}$ and $\mathrm{A}$ treatments, respectively). Plants at the threeleaf stage were inoculated mechanically with each virus isolate. After 6 months, each inoculated plant was tested by ISEM-
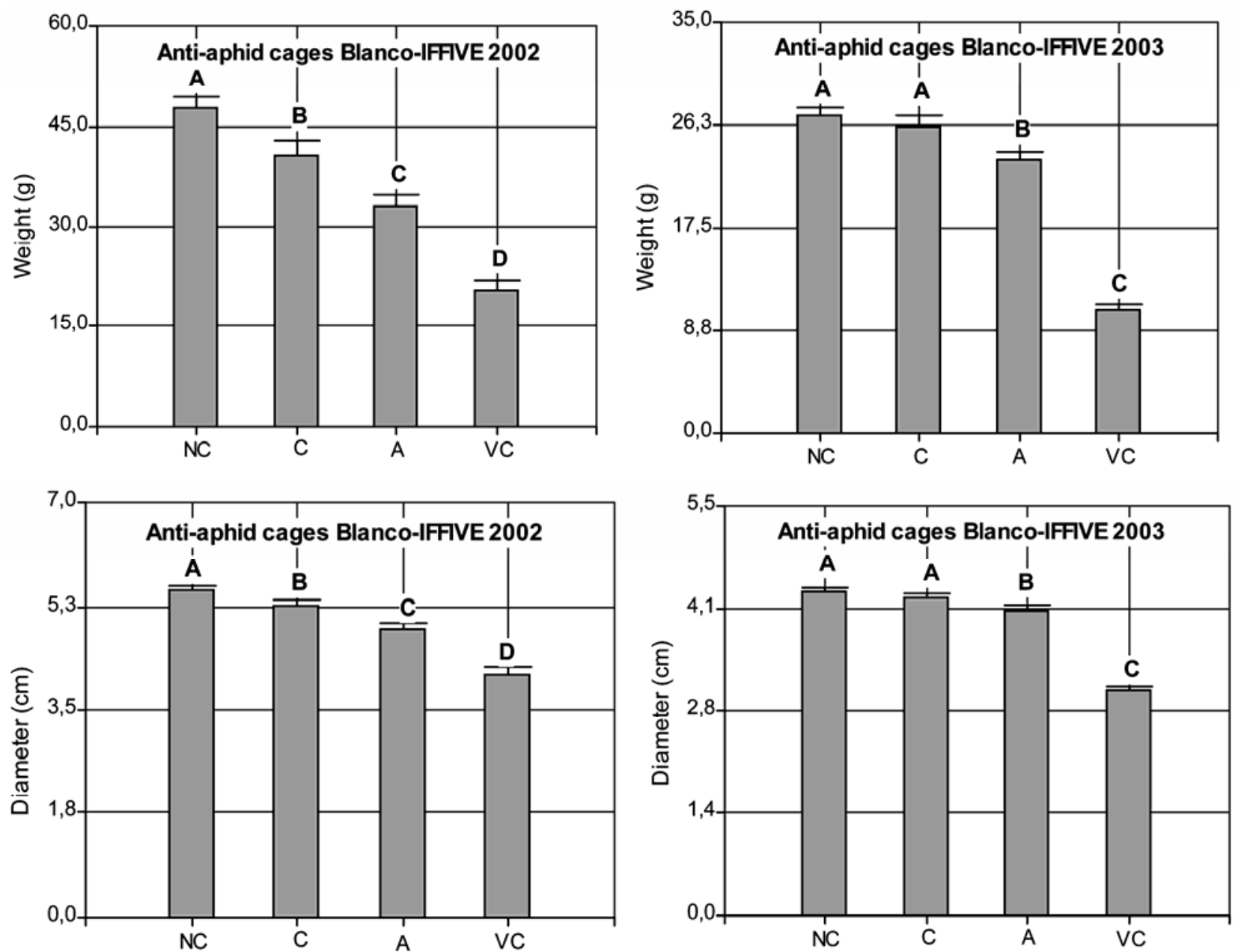

Fig. 2. Effect of Garlic virus A (GarV-A) and Garlic virus $C$ (GarV-C) isolates on weight and diameter of garlic cv. Blanco-IFFIVE in the anti-aphid cage for years 2002 and 2003, respectively. Abbreviations of treatments: NC, negative control; C, C-treatment; A, A-treatment; VC, virus-complex treatment. Bars with different letters are significantly different $(P<0.05)$ based on LSD. 
$\mathrm{D}$ with the antisera mentioned above. Uninfected plants were eliminated. Bulbs produced by infected plants were harvested and stored in a dry place at room temperature (17 to $27^{\circ} \mathrm{C}$ range) until the start of the next crop cycle.

One year before starting the assays, the four treatments (negative control, viruscomplex, C, and A) were planted and multiplied in individual anti-aphid cages ( 2 by $1 \mathrm{~m}$ ), one for each treatment, $10 \mathrm{~cm}$ distant within rows, with $30 \mathrm{~cm}$ between rows in order to obtain bulbs under the same growing and environmental conditions. The sanitary condition of each treatment was tested again by DAS-ELISA and ISEM-D.

Yield assays. The four treatments were compared during two consecutive years (2002 and 2003) in parallel assays, in antiaphid cages and in the field. Cloves of equal size were planted for the assays. Clove size was standardized using two sieves $\left(1.5\right.$ and $\left.1 \mathrm{~cm}^{2}\right)$, which resulted in three size categories. Cloves retained by the second sieve (category 2) were used for treatments and assays. Three days prior to planting, cloves were disinfected by immersion for $15 \mathrm{~min}$ in a suspension of captan (Captan Tomen WP 80\%, 25 g), procymidone (Sumilex $50 \mathrm{SC} 50 \%, 15 \mathrm{~g}$ ), pentachloronitrobenzene (PCNB, WP 78, $2 \%, 15 \mathrm{~g}$ ), and benomyl (Benlate WP 50\%, $25 \mathrm{~g}$ ) in 25 liters of water. The assays were conducted in the research field of the IFFIVE-INTA, Córdoba, Argentina.

Anti-aphid cage assays. Assays were conducted in a randomized plot design, one plot per treatment. Each plot consisted of an anti-aphid cage $(3 \times 1 \mathrm{~m})$. Cloves were planted in each anti-aphid cage in three rows $30 \mathrm{~cm}$ apart and at $10-\mathrm{cm}$ intervals. Plants continued to be infected until the end of the crop cycle, as confirmed by DAS-ELISA and/or ISEM-D.

Field assays. The trials were carried out in four randomized complete blocks for each cultivar and for each year of assay. Each block contained four plots, one for each treatment. The cloves were planted in furrows $60 \mathrm{~cm}$ apart and at $15-\mathrm{cm}$ intervals. The cloves used in the assays were obtained from the anti-aphid cages in the previous crop cycle.

Each experimental plot in each block included 20 cloves. Random samples of 28 plants in 2001 and 25 plants in 2002 were taken from each treatment to evaluate virus infection by DAS-ELISA with OYDV,
LYSV, and GarV-A antisera. The relative virus concentration (RC) was calculated for each year and treatment to compare the DAS-ELISA absorbance values for different viruses and at different times (15). The $\mathrm{RC}$ was calculated as the ratio between the DAS-ELISA absorbance value (measured at $405 \mathrm{~nm}$ ) of the sample and the mean plus twice the standard deviation of the DAS-ELISA absorbance of five healthy control samples tested in the same plate. Absorbance readings were measured with a Dynatech MR 4000 spectrophotometer (Dynatech, Guernsey Channel Islands, UK).

The plants were irrigated every 7 to 10 days. After harvest, bulbs were stored dry at room temperature. Bulb weight and diameter were recorded 30 days after harvest. Bulb weight was measured with a precision balance, and diameter was recorded at the greatest equatorial diameter of the bulb with a digital caliper. The treatments were compared by ANOVA. When needed, LSDFisher multiple comparisons test was applied. The statistical analyses were carried out with InfoStat statistical software (Version 2004, Grupo InfoStat, Facultad Ciencias Agropecuarias, Universidad Nacional de Córdoba, Argentina).
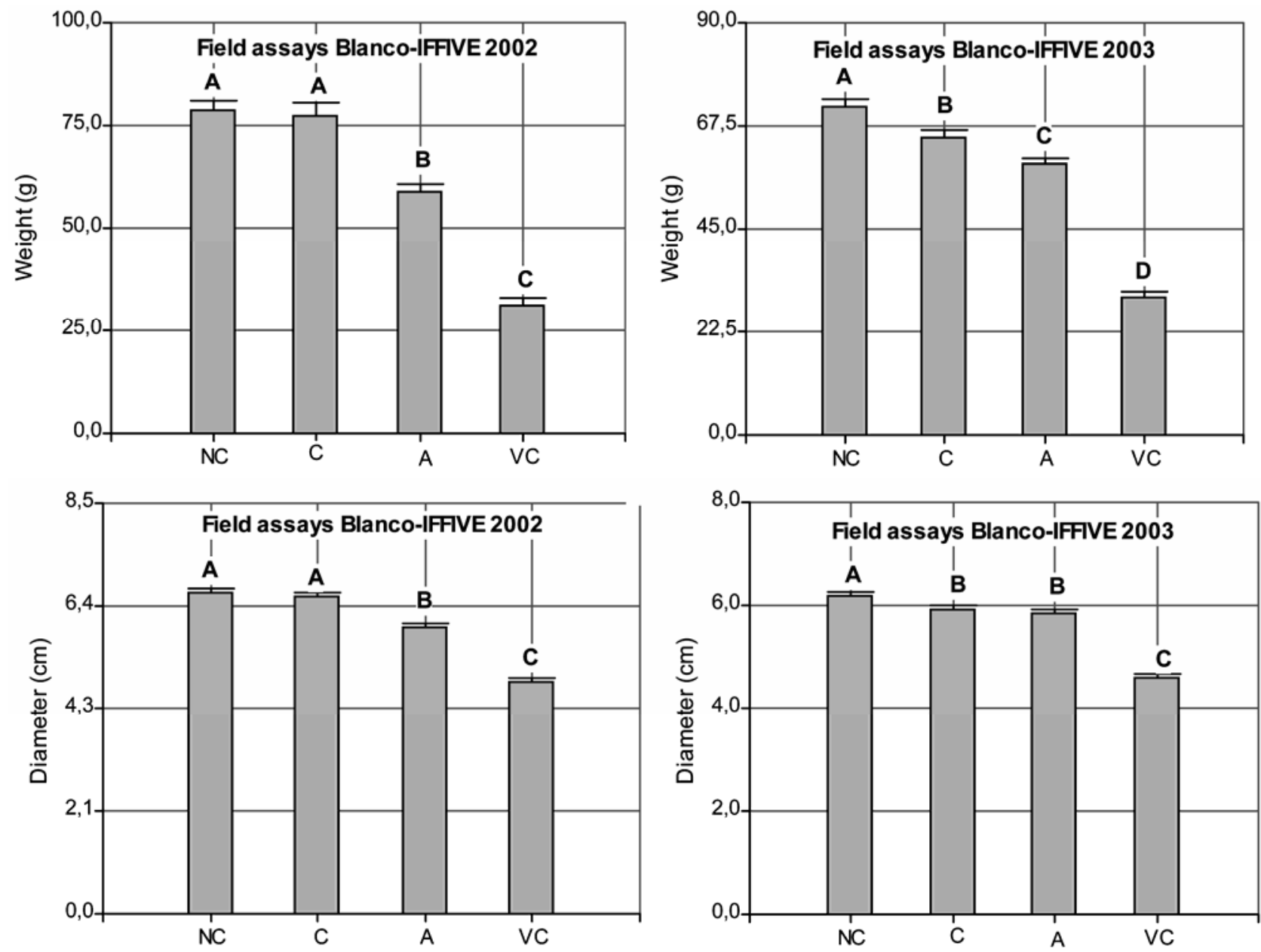

Fig. 3. Mean weight and diameter of garlic bulbs in treatments of cv. Blanco-IFFIVE in field assays for 2002 and 2003 , respectively. Abbreviations of treatments: NC, negative control; C, C-treatment; A, A-treatment; VC, virus-complex treatment. Bars with different letters are significantly different $(P<0.05)$ based on LSD. 


\section{RESULTS}

Results varied with the virus isolate tested (Fig. 1). Bulb weight and diameter were reduced significantly by GarV-A in the cv. Blanco-IFFIVE in anti-aphid cage assays, in the 2 years of assays (Fig. 2). A reduction of 32 and $14 \%$ in bulb weight and of 11 and $6 \%$ in diameter was observed for each year, respectively. A marked reduction in A-treatment yield with respect to the negative control was also observed for the two variables evaluated in both years in the field assays (Fig. 3 ). Losses of 25 and $17 \%$ in bulb weight and 10 and $5 \%$ in bulb diameter were detected for 2002 and 2003, respectively.

The yields of plants infected with GarV$\mathrm{C}$ in anti-aphid cages were significantly smaller than the yields of negative control in the 2002 assay. A $15 \%$ reduction in bulb weight and $5 \%$ in diameter were observed. In both years, C-treatment produced bulbs of significantly greater weight and diameter than A-treatment (Fig. 2). In the field assay, no significant differences were detected between $\mathrm{C}$-treatment and negative control in 2002; however, differences were significant in 2003 assays, with a 9\% reduction in bulb weight and $4 \%$ in diameter. The isolate GarV-C caused significantly less effect on yield than isolate GarV-A for both yield variables evaluated, except for diameter in the second year in the field assay (Fig. 3).

The virus-complex treatment caused the greatest damage to yield, and the losses were statistically significant for all treatments tested in both years. Weight losses of up to $61 \%$ and diameter reductions of up to $30 \%$ with respect to the negative control were detected (Figs. 2 and 3).

In cv. Morado-INTA in anti-aphid cages, GarV-A significantly reduced bulb weight and diameter compared with the negative control during the 2 years of assay (Fig. 4). Reductions of 25 and $14 \%$ in weight and 11 and $7 \%$ in diameter were detected in 2002 and 2003, respectively. In field assays, a significant bulb weight and diameter reduction was observed in A-treatment with respect to the negative control (Fig. 5), with losses of 27 and $31 \%$ in weight and of 8 and $10 \%$ in diameter in 2002 and 2003, respectively. Losses in bulb weight and diameter in A-treatment in field assays were higher than those detected for the virus-complex treatment, taking into account that differences in the virus-complex treatment with respect to negative control were nonsignificant in 2003. The A-treatment was not significantly different from virus-complex treatment only in bulb diameter in 2002.

The C-treatment did not differ significantly from negative control in yield in either of the two assay conditions tested (anti-aphid cages and field assays) in the 2 years (Figs. 4 and 5). The bulbs in the Ctreatment were significantly heavier and larger than in the A-treatment.

High percentages of OYDV infection were detected in plants in the field assays. In the 2002 experiment, $100 \%$ of the plants of all treatments of the two cultivars were infected with this virus. In 2003, however, percentages ranged from 36 to $88 \%$. LYSV infection was lower than that recorded for OYDV. The percentages of LYSV infection ranged from 7 to $75 \%$ in 2002, and from 4 to $56 \%$ in 2003. Infections with GarV-A were different in the 2 years of assays. The extreme infection values in 2002 ranged from 4 to $36 \%$, whereas in 2003 GarV-A infection was very low, being almost absent in some treatments, such as Ctreatment in cv. Blanco-IFFIVE and negative control in cv. Morado-INTA (Table 1).

The analysis of viral concentration (evaluated through RC) in cvs. BlancoIFFIVE and Morado-INTA in 2002 revealed a high concentration of OYDV in all treatments; however, in $2003 \mathrm{RC}$ values were lower (Table 1).

\section{DISCUSSION}

This work is the first report in which the effect of two isolates of Allexivirus, GarV-
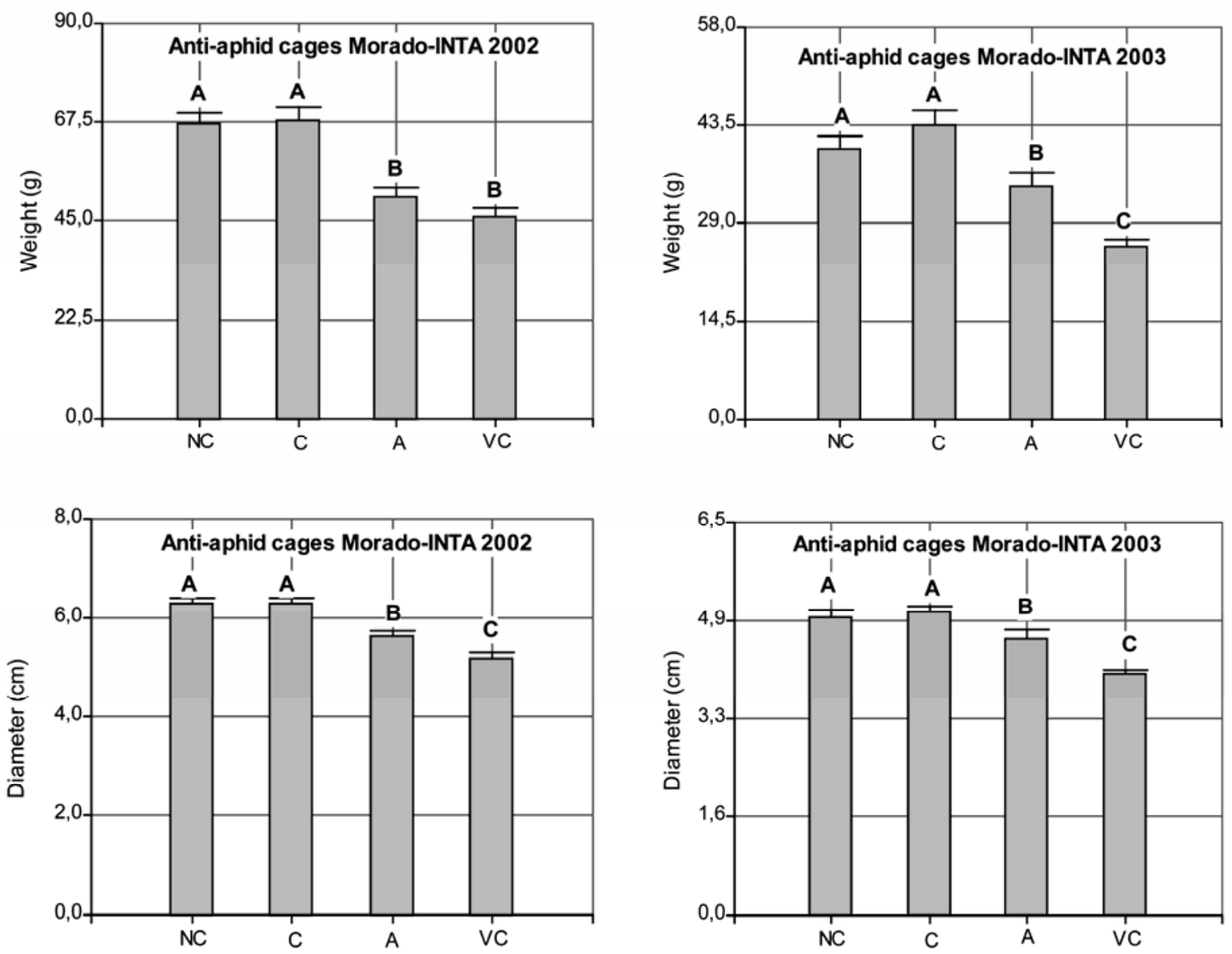

Fig. 4. Effect of Garlic virus A (GarV-A) and Garlic virus $C$ (GarV-C) isolates on weight and diameter of garlic cv. Morado-INTA in the anti-aphid cage for 2002 and 2003, respectively. Abbreviations of treatments: NC, negative control; C, C-treatment; A, A-treatment; VC, virus-complex treatment. Bars with different letters are significantly different $(P<0.05)$ based on LSD. 
$\mathrm{C}$ and GarV-A, on garlic crop yield is evaluated. The development of this kind of study has been hampered by the difficulties in isolating viruses from the garlic viral complex. In fact, there are no differential hosts that facilitate isolation of either virus easily and quickly. Furthermore, maintaining and multiplying virus isolates on garlic plants for comparative yield assays is also difficult. The greatest difficulty lies in the lack of plants naturally free of virus. Because garlic is propagated vegetatively, viruses persist over successive generations. Virus-free garlic plants are obtained through meristem culture $(16,40)$, a long process that requires at least 1 or 2 years to produce virus-free plants in vitro, transfer them to ex vitro conditions, and harden them so that they readapt to normal crop conditions. These stages are highly risky, since plants are easily reinfected when they are exposed to the normal cultivation conditions in the field near infected garlic plants. Of the viruses affecting this crop, potyviruses and carlaviruses are transmitted by aphids in a nonpersistent manner, and allexiviruses are transmitted by eriophid mites, which are common pests in bulbs, making it easier to reinfect the crops. Quick reinfection was observed in this work in the negative control and in the $\mathrm{A}$ and $\mathrm{C}$ treatments in the field assays. Despite these difficulties, it is important to determine the effect of each garlicinfecting virus on yield for the certification programs of bulb-seed garlic to efficiently control garlic mosaic. In this work, it was found that GarV-C, under the conditions studied and in the cultivars tested, caused mild or no damage on garlic yield. In cv. Blanco-IFFIVE, the effect on yield was significant in anti-aphid cages in one year (2002), with reductions in bulb weight and diameter of 15 and 5\%, respectively, compared with the negative control, but in the second year (2003), no effect on the yield was observed. When Ctreatment was evaluated in the field, in spite of the fact that plants became naturally infected, in the 2003 assay, significant losses were detected in weight and diameter in low percentages (9 and $4 \%$, respectively). In cv. Morado-INTA, no significant effects were detected on the yield variables evaluated in anti-aphid cages and in field assays in both years. The results in C-treatment were similar to those reported by Takaichi et al. (32), who mentioned little yield reduction by virus infection with a single unidentified mite-borne virus species. The virus evaluated by Takaichi et al. (32) probably was $\mathrm{GraV}-\mathrm{C}$, considering the low effect on yield found.

GarV-A was the Allexivirus species that most affected yield in this work. In both cultivars and both years, this virus caused losses that ranged from 32 to $14 \%$ in bulb weight and from 11 to $6 \%$ in diameter with respect to negative control, observed in anti-aphid cage assays. This is the first time that an Allexivirus has been reported to cause a severe effect on yield. This is important considering that GarV-A is a widespread virus in the garlic production regions $(8,20,21,26,31,33)$.

Important yield losses were detected in the virus-complex treatment in cv. BlancoIFFIVE ranging between 61 and $57 \%$ in bulb weight and between 30 and $26 \%$ in diameter in 2002 and 2003, respectively. This marked reduction in yield in chronically infected bulbs compared with virusfree plants was also observed by other authors in different garlic cultivars $(4,24,39)$. However, it was also observed that in cv. Morado-INTA, losses caused by viruses of the virus-complex treatment were not so marked. In fact, a $19 \%$ loss in diameter and a reduction in bulb weight that ranged from nonsignificant to $37 \%$ were detected. These differences in yield between cultivars caused by the effect of viruses were also detected by Walkey and Antill (39), who observed a low yield loss in the cv. Fructidor.

When the viruses infecting each treatment in the field assays were identified, it was observed that all treatments had been
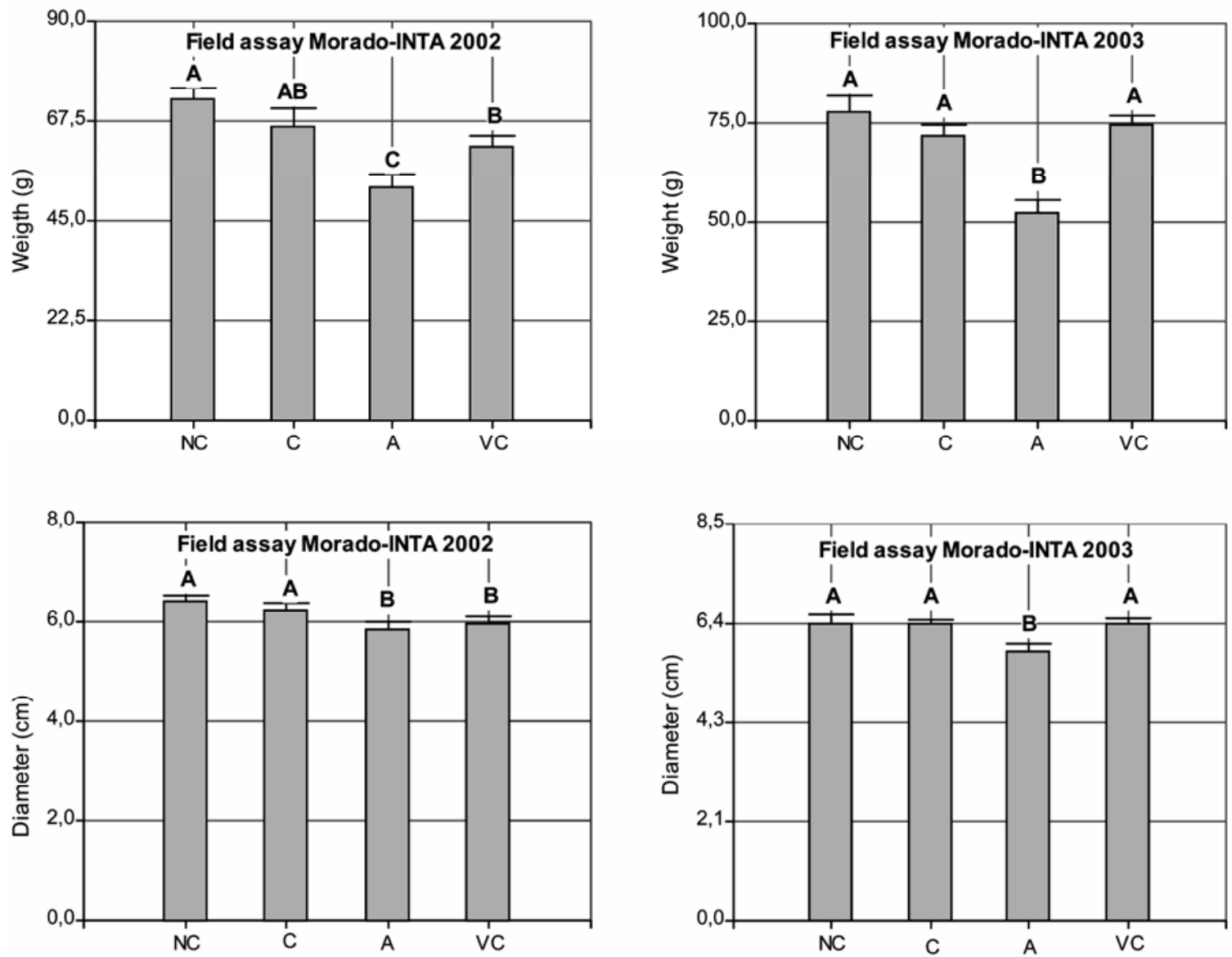

Fig. 5. Mean weight and diameter of garlic bulbs in treatments of cv. Morado-INTA in field assays for 2002 and 2003, respectively. Abbreviations of treatments: NC, negative control; C, C-treatment; A, A-treatment; VC, virus-complex treatment. Bars with different letters are significantly different $(P<0.05)$ based on LSD. 
reinfected in high percentages. These infections might explain some results, such as the lack of yield differences observed in the negative control and the C-treatment in cv. Blanco-IFFIVE in the first year (2002). In contrast, when the assay was repeated in 2003, C-treatment was significantly lower in bulb weight and diameter with respect to negative control. It was also found that in cv. Blanco-IFFIVE, the percentage of plants infected by OYDV in the first year was $100 \%$ in all treatments. Moreover, the analysis of RC of each virus during 2002 showed that the OYDV concentration in the negative control was very high $(\mathrm{RC}=$ 12.4), and higher than that detected in the C-treatment. Considering that OYDV has been cited in previous work causing the greatest yield losses $(4,18,24)$, it can be assumed that the absence of significant difference might be due to the high OYDV concentrations detected in the negative control plants that year. In contrast, in the second year, when significant differences were detected between the two treatments, $64 \%$ of the negative control plants were infected by OYDV, whereas $88 \%$ were infected in the C-treatment. In addition, $\mathrm{RC}$ in the negative control plants was very low $(\mathrm{RC}=1.2)$ compared with $\mathrm{RC}$ detected in $\mathrm{C}$-treatment $(\mathrm{RC}=2.8)$. This probably caused a yield reduction in the $\mathrm{C}$ treatment, and the results were significantly lower than for the negative control.

The effect on yield of viruses GarV-A and GarV-C can be clearly observed under anti-aphid cages; those differences were maintained under natural field conditions, although the plants were infected by other viruses. This indicates that although plants were infected by viruses, yield was not reduced immediately, or that probably the yield reduction depends on certain virus combinations. Yield reduction does not appear to occur in a short time. Conci et al. (13) also detected that when virus-free plants become infected, yield declines over successive crop cycles, and that even after five crop cycles exposed to infection, the plants still do not suffer the yield loss values of virus-complex plants. The reason why yield losses have not been detected despite the occurrence of reinfection has not been elucidated yet. Results of the assays conducted in this work have shown that, apparently, the viruses that previously infected the plants had a greater influence than those viruses more recently acquired, since the effects on yield were similar to those caused by treatments in the antiaphid cage. GarV-C did not affect yield, or reduced it by a low percentage in the antiaphid cage; the C-treatment showed a similar behavior in field assays, despite the infection produced. In contrast, GarV-A caused statistically significant yield losses with respect to the negative control in antiaphid cages; in the field assays, the same differences were observed although negative control plants were infected. Further studies are necessary to elucidate the relationship between yield losses and infection with the different viral species, their combinations and concentrations. The evaluation of the effects of the two Allexivirus isolates studied on bulb weight and diameter, and the significant yield loss caused by GarV-A emphasizes the need to use certi-

Table 1. Percentage of virus-infected plants (\%) and relative concentration (RC) of viruses in field assay plants

\begin{tabular}{|c|c|c|c|c|c|c|c|c|}
\hline \multirow[b]{2}{*}{ Cultivar } & \multirow[b]{2}{*}{ Treatment $^{\mathbf{a}}$} & \multirow[b]{2}{*}{ Antisera $^{\text {b }}$} & \multicolumn{3}{|c|}{2002} & \multicolumn{3}{|c|}{2003} \\
\hline & & & No. ${ }^{c}$ & $\begin{array}{l}\text { VIPd }^{\mathbf{d}} \\
(\%)\end{array}$ & $\mathbf{R C}^{\mathbf{e}}$ & No. ${ }^{c}$ & $\begin{array}{l}\text { VIPd }^{d} \\
(\%)\end{array}$ & $\mathbf{R C}^{\mathbf{e}}$ \\
\hline \multirow{8}{*}{ Blanco-IFFIVE } & A & OYDV & 28 & 100 & 9.9 & 25 & 60 & 1.7 \\
\hline & & LYSV & 28 & 75 & 1.8 & 25 & 20 & 0.7 \\
\hline & $\mathrm{C}$ & OYDV & 28 & 100 & 7.7 & 25 & 88 & 2.8 \\
\hline & & LYSV & 28 & 39 & 1.1 & 25 & 8 & 0.6 \\
\hline & & GarV-A & 28 & 36 & 0.9 & 25 & 0 & 0.3 \\
\hline & $\mathrm{NC}$ & OYDV & 28 & 100 & 12.4 & 25 & 64 & 1.2 \\
\hline & & LYSV & 28 & 21 & 0.9 & 25 & 12 & 0.4 \\
\hline & & GarV-A & 28 & 25 & 0.9 & 25 & 4 & 0.4 \\
\hline \multirow[t]{8}{*}{ Morado-INTA } & A & OYDV & 28 & 100 & 6.1 & 25 & 36 & 1.0 \\
\hline & & LYSV & 28 & 71 & 3.5 & 25 & 12 & 0.3 \\
\hline & $\mathrm{C}$ & OYDV & 28 & 100 & 4.8 & 25 & 80 & 1.7 \\
\hline & & LYSV & 28 & 61 & 3.7 & 25 & 56 & 1.3 \\
\hline & & GarV-A & 28 & 11 & 0.7 & 25 & 28 & 0.9 \\
\hline & $\mathrm{NC}$ & OYDV & 28 & 100 & 4.0 & 25 & 76 & 2.4 \\
\hline & & LYSV & 28 & 7 & 0.7 & 25 & 4 & 0.3 \\
\hline & & GarV-A & 28 & 4 & 0.4 & 25 & 0 & 0.3 \\
\hline
\end{tabular}

${ }^{\mathrm{a}} \mathrm{A}=$ inoculated with Garlic virus A (GarV-A); $\mathrm{C}=$ inoculated with Garlic virus $C$ (GarV-C); $\mathrm{NC}=$ negative control.

${ }^{\mathrm{b}} \mathrm{OYDV}=$ Onion yellow dwarf virus; LYSV = Leek yellow stripe virus; antisera to GarV-C not available.

${ }^{c}$ Number of plants tested.

${ }^{\mathrm{d}}$ Virus-infected plants.

${ }^{\mathrm{e}}$ Relative concentration was calculated as the ratio between the double-antibody sandwich enzymelinked immunosorbent assay (DAS-ELISA) absorbance value (measured at $405 \mathrm{~nm}$ ) of the sample and the mean plus twice the standard deviations of the DAS-ELISA absorbance of five healthy control samples tested in the same plate. fied material and to discriminate the viral species present, since not all of them affect yield similarly.

\section{ACKNOWLEDGMENTS}

This work was partially supported by INTA Agencia Córboba Ciencia, S. E., CONICET and Agencia Nacional de Ciencia y Tecnología FONCyT and CABBIO research grants. We thank $\mathrm{J}$. Burba, (EEA-INTA La Consulta) for providing cy. Morado-INTA. We also thank D. E. Lesemann, $\mathrm{H}$ J. Vetten, E. Barg, L. Bos, D. Z. Maat, S. Sumi, M. Carvalho, and R. Shepherd for kindly providing antisera.

\section{LITERATURE CITED}

1. Barg, E., Lesemann, D. E., Vetten, H. J., and Green, S. K. 1994. Identification, partial characterization and distribution of viruses infecting Allium crops in South and Southeast Asia. Acta Hortic. 358:251-258.

2. Bos, L. 1982. Viruses and virus diseases of Allium species. Research Institute for Plant Protection. Acta Hortic. 127:11-29.

3. Cafrune, E. E., and Conci, V. C. 2002. Aislamiento de Garlic virus C. Page 85 in: XI Jornadas Fitosanitarias Argentinas. (Abstr.) Facultad de Agronomía y Veterinaria, Universidad Nacional de Río Cuarto, Córdoba, Argentina.

4. Canavelli, A., Nome, S. F., and Conci, V. C. 1998. Efecto de distintos virus en la producción de ajo (Allium sativum) Rosado Paraguayo. Fitopatol. Bras. 23:354-358.

5. Carvalho, M. G. 1981. Viroses do alho. Fitopatol. Bras. 6:299-300.

6. Carvalho, M. G., Shepherd, R. R., and Hall, D. H. 1981. Virus em clone de alho sem sintomas e liberto do Garlic yellow stripe virus. Fitopatol. Bras. 6:236.

7. Chen, J., Chen, J., and Adams, M. J. 2001 Molecular characterization of a complex mixture of viruses in garlic with mosaic symptoms in China. Arch. Virol. 146:1841-1853.

8. Chen, J., Zheng, H. Y., Antoniw, J. F., Adams, M. J., Chen, J. P., and Lin, L. 2004. Detection and classification of Allexiviruses from garlic in China. Arch. Virol. 149:435-445.

9. Clark, M. F., and Adams, A. N. 1977. Characteristics of the microplate method of enzyme linked immunosorbent assay (ELISA) for the detection of plant viruses. J. Gen. Virol. 34:475-482.

10. Conci, V. C. 1997. Virus y Fitoplasmas de Ajo. Pages 267-291 in: 50 Temas Sobre Producción de Ajo, Vol. 3. J. L. Burba, ed. Estación Experimental Agropecuaria-Instituto Nacional de Tecnología Agropecuaria. La Consulta, Mendoza, Argentina.

11. Conci, V. C., Cafrune, E. E., Lunello, P., Nome, S., and Perotto, C. 2004. Producción de Planas de Ajo Libres de Virus. Pages 313-316 in: Biotecnología y Mejoramiento Vegetal, Parte VIII, Cap. 6. V. Echenique, C. Rubinstein, and L. Mroginski, eds. Instituto Nacional de Tecnología Agropecuaria, Buenos Aires, Argentina.

12. Conci, V. C., Canavelli, A., Cafrune, E., and Nome, S. F. 1995. Incidencia económica de las virosis en cultivos de ajo. Pages 5-10 in: IV Curso/Taller Sobre Producción, Comercialización e Industrialización de Ajo. Estación Experimental Agropecuaria-Instituto Nacional de Tecnología Agropecuaria. La Consulta, Mendoza, Argentina.

13. Conci, V. C., Canavelli, A., Lunello, P., Di Rienzo, J., Nome, S. F., Zumelzu, G., and Italia, R. 2003. Yield losses associated with virus-infected garlic plants during five successive years. Plant Dis. 87:1411-1415

14. Conci, V. C., Helguera, M., and Nome, S. F. 1999. Serological and biological comparison of Onion yellow dwarf virus from onion and 
garlic in Argentina. Fitopatol. Bras. 24:73-75.

15. Conci, V. C., Lunello, P., Buraschi, D., Italia, R. R., and Nome, S. F. 2002. Variations of Leek yellow stripe virus concentration in garlic and its incidence in Argentina. Plant Dis. 86:1085-1088.

16. Conci, V. C., and Nome, S. F. 1991. Virus free garlic (Allium sativum L.) plants obtained by thermotherapy and meristem tip culture. J. Phytopathol. 132:189-192.

17. Conci, V. C., Nome, S. F., and Milne, R. G. 1992. Filamentous viruses of garlic in Argentina. Plant Dis. 76:594-596.

18. Delecolle, B., and Lot, H. 1981. Viroses de l'ail. I-Mise en évidenceet essais de caractérisation par immunoélectronmicroscopie d'un complexe de trois virus chez defférentes populations d'ail atteintes de mosaïque. Agronomie 1:763-770

19. Dovas, C. I., Hatziloukas, E., Salomon, R., Barg, E., Shiboleth, Y., and Katis, N. I. 2001. Comparison of methods for virus detection in Allium spp. J. Phytopathol. 149:731-737.

20. Filho, P. A. M., Nagata, T., Dusi, A. N., Buso, J. A., Torres, A. C., Eiras, M., and Oliveira Resende, R. 2004. Detection of three Allexivirus species infecting garlic in Brazil. Pesq. Agropec. Bras. 39:735-740.

21. Helguera, M., Bravo-Almonacid, F., Kobayashi, K., Rabinowicz, P. D., Conci, V., and Mentaberry, A. 1997. Immunological detection of a GarV type virus in Argentine garlic cultivars. Plant Dis. 81:1005-1010.

22. Helguera, M., Lunello, P. A., Nome, C., and Conci, V. C. 1997. Advances in the purification of filamentous viruses from garlic and an antisera production. Acta Hortic. 433:623-630.

23. Kanyuka, K. V., Vishnichenko, V. K., Levay, K. E., Kondrikov, D. Y., Ryabov, E. V., and Zavriev, S. K. 1992. Nucleotide sequence of
Shallot virus $X$ RNA reveals a 5'-proximal cistron closely related to those of Potexviruses and a unique arrangement of the 3 '-proximal cistrons. J. Gen. Virol. 73:2553-2632.

24. Lot, H., Chovelon, V., Souche, S., and Delecolle, B. 1998. Effects of onion yellow dwarf and leek yellow stripe viruses on symptomatology and yield loss of three French garlic cultivars. Plant Dis. 82:1381-1385.

25. Lunello, P., Ducasse, D., Helguera, M., Nome, S. F., and Conci, V. C. 2002. An Argentinean isolate of Leek yellow tripe virus from leek can be transmitted to garlic. J. Plant Pathol. 84:11-17.

26. Lunello, P., Helguera, M., Bravo Almonacid, F., Kobayashi, K., Nome, S. F., Mentaberry, A., and Conci, V. 2000. Distribution of Garv-A virus in different garlic production regions of Argentina. J. Plant Pathol. 82:17-21.

27. Lunello, P., Nome, S., and Conci, V. 1999. Resultados preliminares sobre el efecto del Leek yellow stripe virus (LYSV) en el cultivo de ajo. (Abstr.) Fitopatología 34(4):178.

28. Milne, R. G., and Luisoni, E. 1977. Rapid immune electron microscopy of virus preparations. Page 265-281 in: Methods in Virology. K. Maramorosch and H. Koprowski, eds. Academic Press, New York.

29. Song, S. I., Song, J. T., Kim, C. H., Lee, J. S., and Choi, Y. D. 1998. Molecular characterization of the Garlic virus $X$ genome. J. Gen. Virol. 79:155-159.

30. Sumi, S., Matsumi, K. T., and Tsuneyoshi, T. 1999. Complete nucleotide sequences of garlic viruses $\mathrm{A}$ and $\mathrm{C}$, members of the newly ratified genus Allexivirus. Arch. Virol. 144:1819-1826.

31. Sumi, S., Tsuneyoshi, T., and Furutani, H. 1993 Novel rod-shaped viruses isolated from garlic, Allium sativum, possessing a unique genome organization. J. Gen. Virol. 74:1879-1885.

32. Takaichi, M., Nagakubo, T., and Oeda, K.
2001. Mixed virus infections of garlic determined by a multivalent polyclonal antiserum and virus effects on disease symptoms. Plant Dis. 85:71-75.

33. Tsuneyoshi, T., and Sumi, S. 1996. Differentiation among garlic viruses in mixed infections based on RT-PCR procedures and direct tissue blotting immunoassays. Phytopathology 86:253-259.

34. Van Dijk, P. 1993. Carlavirus isolates from cultivated Allium species represent three viruses. Neth. J. Plant Pathol. 99:233-257.

35. Van Dijk, P. 1993. Survey and characterization of Potyviruses and their strains of Allium species. Neth. J. Plant Pathol. 99. Suppl. 2:1-48

36. Van Dijk, P., and Van Der Vlugt, R. A. 1994 New mite-borne virus isolates from rakkyo, shallot and wild leek species. Eur. J. Plant Pathol. 100:269-277.

37. Van Dijk, P., Verbeek, M., and Bos, L. 1991. Mite-borne viruses from cultivated Allium species, and their classification into two new $R y$ moviruses in the family Potyviridae. Neth. J. Plant Pathol. 97:381-399.

38. Van Regenmortel, M. H. V., Fauquet, C. M., Bishop, D. H. L., Carstens, E. B., Estes, M. K. Lemon, S. M., Maniloff, J., Mayo, M. A., McGeoch, D. J., Pringle, C. R., and Wickner, R. B. 2000. Virus Taxonomy. Seventh Report of the International Committee on Taxonomy of Viruses. Academic Press, San Diego.

39. Walkey, D. G. A., and Antill, D. N. 1989. Agronomic evaluation of virus-free and virus infected garlic (Alliurn sativurn L.). J. Hortic. Sci. 64:53-60.

40. Walkey, D. G. A., Webb, M. J. W., Bolland, C. J., and Miller, A. 1987. Production of virusfree garlic (Allium sativum L.) and shallot ( $A$. ascalonicum L.) by meristem-tip culture. J. Hortic. Sci. 62:211-220. 